\section{THE HARMONY BETWEEN NATURE AND MAN IN THAI POETRY ${ }^{1}$}

\section{Suchitra Chongstitvatana ${ }^{2}$}

\begin{abstract}
The paper is an attempt to investigate the concept of harmony between nature and man expressed in Thai poetry from the past to the present to see to what extent this concept has persisted through the change of time and to what extent it has changed.
\end{abstract}

The texts of Thai poetry selected for the study are poetical works of Prince Dhammadhibet of the Ayudhya period, Inao by King Rama II of the Rattanakosin period and the contemporary works of Angkhan Kalayanapong, especially the text of $Y a$, or Grandma.

All the texts selected express a harmonious relationship between nature and man. In Thai literary conventions, nature is used to express love, joy and pain, especially in the Nirat genre. This is perfectly conveyed in Prince Dhammadhibet's works as well as Inao of King Rama II, where love themes are most prominent. Whereas in Angkhan Kalayanapong's poetry, the poet observes both the conventional

${ }^{1}$ This paper was presented at the $3^{\text {rd }}$ Euroseas Conference on Panel 23 : "SouthEast Asian literatures and their concept of the human world" held in London from 6-8 September, 2001.

$2 \mathrm{Ph} . \mathrm{D}$., Assistant Professor, Department of Thai, Faculty of Arts, Chulalongkorn University, Bangkok, Thailand. concept of Nirat genre, like the poets of the past, and a more individual concept of his own.

\section{Harmony in the 'Ideal' World : Nature and Man in Classical Thai Poetry}

Nature has always been one of the most significant elements in Thai poetry. The art of describing nature in the most elaborate details possible is perhaps characteristic of classical Thai poetry. This literary technique is evidence of the poet's attachment to nature and the harmonious co-existence between nature and man.

In Traibhumikatha by King Lithai, a unique text of Thai cosmology, the harmony between nature and man in the ideal world is beautifully described as follows.

The Himavanta mountain range is 500 yojana high and 3,000 yojana wide, and has 84,000 peaks. A large jumbolan tree grows at the foot of Mount Himavanta. This tree stands on the banks of a river named Sida Nadi, the River of Coolness. The trunk of this jambolan is 15 yojana around. The height from the ground up to where the trunk forks is 50 yojana, and from its fork to the tree-top is 50 more. The width from the tip of the easternmost branch to the tip of the westernmost one is 1,000 yojana; from the southernmost tip to the northernmost one is $800,000 \mathrm{wa}^{3}$,

${ }^{3} \mathrm{~A}$ Thai measurement equals about 2 metres. 
and $2,400,000$ wa around. Jambolan flowers are marvelous in beauty and fragrance. The fruit are as big as large drums and taste as sweet as honey. When they chance to fall and someone touches them, they leave a fragrance as delightful as perfume distilled from the core of the sandalwood. Should a man push a fist into the flesh of the fruit, his whole arm would be buried in it before he reaches the seed. Some of the birds that feed on the fruit of the jambolan tree are as large as houses; some are as huge as elephants. Jambolan fruit fall all around the tree. In the south, they fall into the river and are eaten by the fishes. The sap of the jambolan drops into the water and turn into the purest gold known as Jambunuda

Beyond the jambolan tree lies a grove of Indian gooseberies with large and delectable fruit. Further beyond stands a grove of samo trees whose fruit are honey-sweet. Next to this latter grove flow the seven great rivers. Beyond these is a grove of jambolan whose fruit is like honey. The expanse of this grove is 4,000 wa. Next is a forest of Nariphala, maiden fruit trees whose fruit is exquisitely shaped like a sixteen-year-old maid having freshly reached womanhood. The sight of them stirs men's hearts with desire; and when they drop to the ground, birds flock to eat them as greedily as bears eat beehives. This forest tapers eastward towards the ocean; to the west it tapers towards the seven great rivers, occupying an expanse some 100,000 wa wide. $^{4}$

From the text above, the harmonious coexistence between nature and man is highly emphasized in the style of hyperbole. We can notice the role of nature as a giver or 'pleasure-supplier' for man by providing abundant satisfaction in all the needs of man. Besides, it seems evident that man is fortunate enough to get all this satisfaction without much effort, thanks to the 'generosity' of nature.

This concept of the abundance and generosity of nature is quite persistent throughout Thai poetry and has been a strong influence in the creation of Thai literary convention concerning the description of nature.

In the Nirat genre of Thai poetry the harmonious co-existence between nature and man is well attested, as can been seen from the way the poet employs all the elements in nature in his expressions of joy and sorrow during his journey away from his beloved.

In the famous Kap He Rua of Prince Dhammadhibet of the Ayudhya period, we can see how the poet perceives the nature around him with precision and detail.

He describes the flowers, birds, fish and the behaviour of animals with the marvelously realistic details of a natural

${ }^{4}$ King Lithai, Traibhumikatha : The Story of the Three Planes of Existence, trans. The Thai National Team (Bangkok : The ASEAN Committee on Culture and Information, 1985), p. 395. 
scientist. Yet at the same time, he uses all elements of nature to express his own self and feelings. This means that, to a certain extent, the poet identifies himself with the nature he perceives and recreates a 'heart-felt' nature of his own.

\section{The Harmony of 'Realistic' and 'Heart-Felt' Nature}

The marvelous harmony of 'realistic' and 'heart-felt' nature expressed in Thai poetry is a result of the poet's attachment to nature and his mastery of language use. One of the elements of nature the poet uses to convey his feelings is the names of trees, flowers and animals that could be used as 'puns' and 'word-plays' in the text. (This makes it quite impossible to be translated into another language!)

The texts of 'Musing on the Flowers' and 'Musing on the Bird' in the Kap He Rua of Prince Dhammadhibet are excellent examples of the harmony between 'realistic' and 'heart-felt' nature in Thai poetry of the Ayudhya period.

Thus, it is worth looking at the texts (even though in translation) to understand this harmony, that is essential in the creation of literary convention

\section{MUSING ON THE FLOWERS}

Coasting the river's leafy bank Varied flowers vie in fragrance Scented buds blow in profusion As heady as the scent of my dear love
Coasting the river's leafy bank Where flowers grow in lavish abandon

Scented buds blow in profusion

Recalling the perfume of my sweet love

Seeing the blossoms of Smiling Lady

Whose tender petals have begun to unfurl

I recollect your petal lips which curls

And wreathes into the loveliest of smiles

Thickly blooming Champa unfolds

Its gentle petals in yellow luxuriance

I recall the gold of your complexion

Excelling the magnificence of golden Champa

Prayong trails its blossoms

Festooning itself with dangling blooms

Like garlands you used to hang in my room

Floral ornaments you so lovingly wreathed

Fragiled-petaled Pudjeep

Peeps out among Pikul and Sukrom

Scenting the soft-blowing wind Like your soft unforgettable scent

Saoyud and Buddhachard Are blooming in lavish opulence Reminding me of the leis you wroughted

And laid out for me by my bed 
Fragrant Pikul and Bunnag

Infuse the air with alluring sweetness

Were you here with me, my enchantress,

How you'd beseech me to gather them

Teng, Taew, Kaew, Kalong Unfurl and breathe forth their perfumes

As lastingly redolent as the sweet infusion

That bescents my dearest's dresses

Maliwan entwines Jik and Juang

Dusting powdery pollens from its blossoms

A wind-wafted redolence so winsome

That my thoughts wander back to you

Voluptuous Lamduan spreads

Its heady scent that arouses memories

Of the intricate and perfumed potpuri

How sadly I yearn for you

Softly wafts the fragrance of Rampoey

Like the cheeks I was wont to kiss

I was used to staying close to my sweet

Never allowing a distance between us

\author{
Beautiful is the array of \\ flowers \\ Flourishing in countless \\ varieties \\ Had my dear love been here \\ with me \\ Together we would share the \\ joy
}

The above text clarifies how the poet blends and harmonizes the 'reality' in nature - the names, the colours and the scents of the flowers with the 'feelings' of love longing, of joy and sorrow in his own heart. This harmony re-emphasizes the 'oneness' between the poet's 'self' and the nature he perceives, whereas the poetical art of pun and word play enables him to 're-create' an exquisite description of nature so rich and so real to the perceptions of the readers.

Similarly in the text Musing on the Bird the poet identifies himself with the nature around him in order to express his suffering.

\section{MUSING ON THE BIRD}

Longing, oh, longing, the sun declines

Sighing, oh, sighing, daylight dies in dusk

Longing, oh, longing, my heart sighs for you

Sighing, oh, sighing, I yearn for your soft glance

Sighs, oh, sighs of longing

With the setting of the sun

Softly the evening darkens

And fills with the vision of you

${ }^{5}$ Prince Dhammadhibet, Verse for the Royal Barge Procession, trans. Khunying Chamnongsri Rutnin (Bangkok : T'NAT Printing Press, n.d.), pp. 21-23. 
Sighs, oh, sighs of yearning Flying birds slant the sky One flies alone without a mate As alone and lonely as I

Seeing Peacocks dance and turn

But I yearn for your nimble grace

Demurely steps Golden Necklace

Like my shy beauty pacing her dainty path

Mynah Birds perch in pairs

Feathered lovers in tender passion

But I am drowned in drear desolation

Not to find you within my sight

Million birds of myriad breeds

Trill songs that set the forests echoing

I feel the grief in my heart deepening

Listening to anthems of a thousand tongues ${ }^{6}$

As the atmosphere of sunset normally conveys the sorrow and sadness in one's heart, the poet intensifies this sadness with the lamentation of his longing and painful vision of his beloved.

This literary technique of harmonizing the poet's self with the nature around him can be found throughout the masterpieces of Thai poetry. Inao of King Rama II is an excellent example to illustrate this point.

As. a story from Panji Romance, Inao has as its setting a vast variety of nature forests, mountains, caves, rivers, streams and water-falls. The poet makes

${ }^{6}$ Ibid., p. 25-27. use of beautiful nature to increase the romance of Inao, an exceptionally charming warrior hero.

The most famous and best known episode of Inao is when he is trying to win the heart of Busaba, his fiancée, whom he refuses to marry before having seen her exquisite beauty. Busaba is forced to become the fiancée of Joraka, an inferior prince who has nothing to offer but his devotion to her.

Inao is in great distress trying to win back Busaba and to fight for her, despite all the unfavorable circumstances.

The following excerpts are from the best known episode in Inao when the whole court is travelling in the beautiful forest and Inao is trying his best to be near Busaba. The scene is the forest at night under the full moon and Busaba is enjoying the beauty around her.

The most beloved Busaba

Is travelling in the precious chariot

Along the forest way

When Night gliding by

Busaba looks over the window

Admiring the radiant full Moon

Whose rays embrace the chariot

While the torch light embrace the woods!

The fragrance of wild flowers

Softly singing all around

Busaba asks Bayan to look for the flowers

The whole place is profoundly perfumed!

The songs of insects are melodious

Rhyming with the peacocks' chanting 
Resounding in the wild forest Filling the heart with enchanting joys! $!^{7^{*}}$

The 'heart-felt' nature of the poet is artistically expressed here. The main purpose of the poet is to impress the reader with the exquisite beauty of Busaba and the harmony of her beauty with the wondrous joy of the full moon night.

This exquisite beauty is essential at this point in the story because Inao is hiding not far away, trying to get a glimpse of Busaba's face.

The whole atmosphere of beauty of the night is intensified by the description of 'sensual' pleasure, like the fragrance of the flowers and the music of insects and birds. These elements are 'realistic' enough in the description of a tropical wild forest. Yet the poet manages to add a 'magical' element, which is the presence of the exquisite beauty of Busaba, in order to render a unique significance to the description of this full moon night.

The next example from Inao is an excerpt describing the scene when Inao is enjoying the waterfall in the woods while musing on how Busaba would admire the same beauty if she were next to him.

Arriving at the crystal stream Inao takes a shower from the waterfall

The water is falling in profusion From the great high rocks above

${ }^{7}$ King Rama II, Inao (Bangkok : Silapabanakarn, 1971), p. 443. "translated by Suchitra Chongstitvatana.
Longing for his precious

Busaba

Inao wishes her to be near

So she could enjoy herself in water

And be enchanted by the fish

So varied so beautiful in water so clear

She would pick up shining pebbles

Loitering along the gold sand bank!

The Sok tree by the stream Is shady under the bright sun

She would pick up flowers for garland making

And sing sweetly with heartful joys! ${ }^{8}$

Here we can see nature as a harmonizing element in bringing Busaba nearer to Inao, even though it is only his own imagination. Inao's satisfaction and joy in this beautiful nature is much increased through his longing for Busaba's presence. This longing is powerful enough to make Inao visualize how Busaba would enjoy all the seducing pleasure of nature as he is enjoying now.

Nature and Man in Modern Thai Poetry : A Bond of Love and Wisdom

In modern Thai poetry, the works of Angkhan Kalayanapong are perhaps the most outstanding illustrations of how the concept of harmony between nature and man still persists on in Thai poetry.

Angkhan's masterpiece Lam Nam Phu Kradung is a celebrated evidence of the poet's devotion to nature and his

${ }^{8}$ Ibid., p. 496. 
passionate advocation for a better and kinder attitude and treatment of nature by man.

Though Angkhan employs the convention of Nirat genre in this work, Lam Nam Phu Kradung is far from being a poem of conventional Nirat.

The poet laments the lack of love in human's heart, not only his own lack of a beloved one. He declares his love and devotion to nature with a great passion unknown in any previous Nirat poem. The aspect of nature he admires and respects with all his heart is not just the outward beauty of nature. He points out the 'abstract' or the 'spiritual' beauty of nature as a Dharma giver for all humanity. Therefore, he declares that nature is his great teacher and should be highly revered. ${ }^{9}$

Angkhan's view of Nature as a great teacher and a Bodhisattava is apparent throughout his poetical works, but here we are going to focus on a famous prose-poem Ya or Grandma to explore in more detail how the harmony between man and nature in modern Thai poetry is expressed.

\section{"GRANDMA"}

One twilight during the rainy season, the downpour has come to an end, leaving a trail of clean white clouds moving in gentle procession. The bushes and the

9 see Suchitra Chongstitvatana, "The Green World of Angkhan Kalayanapong : A Vision on Nature and Environment," in Thai Literary Traditions (Bangkok : Chulalongkorn University press, 1995), pp. 148-157. flowering trees turn a brilliant and refreshing green. The setting sun, a ball of red, radiates its beams, bringing forth the rainbows that dine on the droplets left behind. Behind the high mountains, the wind blows gently, shaking the glistening raindrops off the leaves of the mahogany and rubber trees. Down there is a lonely hamlet, a great distance from the centre of things.

An old woman, crumbling from her years, lives in an old hut in the middle of a deserted field. Her hair is the colour of fog and her face is wrinkled and dried, though the centre of her eyes still sparkle. But she is in the dusk of her day, over eighty years of age, her body bent over into a widow's hump.

She belongs to the age of grandmothers, but is without relatives or friends. For many years she has been picking greens in the field and splitting logs to sell for a living. Now she has grown thin and is constantly ill, missing her meals when there is nothing to eat. One day, after recovering from her most recent illness, she had craved some rice and liang curry ${ }^{10}$, a curry made of the greenest vegetables. She notices the tamlyng shoots quivering seductively in the wind. Just at the moment she was reaching toward the vine to pluck one of the shoots, another shoot spoke out:

\footnotetext{
${ }^{10} \mathrm{~A}$ kind of clear soup of various vegetables.
} 
"Grandma, please pick me first. That shoot there is my younger sister. Wait until tomorrow, and maybe then she'll have something to talk with you about."

Grandma was at first dumbfounded and then perplexed, but she gathered her courage and answered, "Of course, for most people on this earth, there'll be a tomorrow, but for me, today is always the last day. Nothing is certain. Tomorrow morning when the cock crows close to three o' clock maybe I will have breathed my last. I have already come that close, many times. So today I want to eat some liang curry to my heart's content."

The tamarind shrub, entering the conversation, asked her "Do you have any rice?"

"Well, some. I bought about four or five litres a few days ago. But there's only a little more than a litre left, and it's full of weevils. I'll have to pick them out first.

By the time the rice is cooked, the night spirits will be out and it will be time to light the torch."

As soon as the old woman finished her words, the yellow papaya, so ripe that it was ready to fall, said in a loud but trembling voice, "Grandma, take this rich ripe papaya to eat first." Grandma had not yet recovered from her amazement, but she expressed her deepest gratitude to these plants.

The papaya said repeatedly:

"Take me first to eat. I have a laxative that will clean your intestines and will make you feel more relaxed. Then you will make yourself forget your concerns and worries, feel in a pleasant frame of mind, enjoy the rainbow or the seven gleaming rays of the morning sun, wake up early in the morning breathing in the pure and fresh air, welcoming the deity of the new day, who will bestow upon you the divine ray of happiness and will prolong your life span. Grandma, you will have a tomorrow that will go on and on for as long as you wish."

Grandma asked, "How can plants talk? In earlier days you were so quiet as to be mute. Or perhaps your compassion lies secreted deeply within you. You are able to bring forth your generosity and your magnanimous mercy so that I can feel the delight of the divine power that has revived my strength and vigor."

At that moment, all the plants of the field declaimed in chorus: "Although we share the same world with human beings, we are immune to the influence of mankind's basic character and thought, which is composed of selfishness, small-mindedness, and avarice. By no means do we follow the human example 
of pretense, deception, and intrigue. Other than grandma, we communicate with no body. We see that you are deserted and ignored uncompassionately by the rest of mankind. Because of the deep pathos we feel for you, we can no longer refrain from speaking.

"In fact, the deities have bestowed souls on all living things, but we prefer to be mute. Even though we have our own language, we act as if we did not. We sometimes communicate with each other in our own language, but it is too mystifying to be understood by any human being. At first, we thought that grandma would breathe her last tonight. But we were fortunate to realize that through the intercession of Divine happiness you have regained your strength, prolonging your life much further."

Grandma listened intensely, deeply moved by the chorus.

Immediately, the watercress in the pond behind the hut said, "Grandma, I will put forth new, fresh leaves for you to pick and sell every day in the market. In the future there will be more people in this area, so my price will increase. Grandma, proclaim to everyone that watercress is a superb medicine. After eating me, people's eyesight also improves."
The old woman was so touched that tears streamed down her cheeks. She kneeled down, lowered her body, and raising her hands to her forehead to pay respect, she expressed her gratitude to Mother Earth and all the vegetables and plants, saying: "Grandma really doesn't want to be any trouble at all to you."

"When I pick you, don't you feel any pain?"

The watercress, quivering in the wind, laughed and said, "Only the Deities in heaven have such exquisite compassion. Grandma, do you think that the Gods that created us would have also bestowed upon us the feeling to know pain? The whole world then would be filled with the cries of our mourning and the screams of our agony as a result of the way we are treated every day and night by human beings. We do speak and we do feel many things, but this is because of the wondrous power of our souls.

"Fortunately, we plants have a nervous system that does not know pain. If we were any different, the torment and misery would be too great to bear, and we would just die. Come, Grandma, please pick me. I am always happy to produce fresh, new leaves."

After that day, the watercress in the pond grew longer and larger, putting forth beautifully more stems and fresh leaves. 
The old woman picked them to sell at the market, earning enough to pay for her rice and other food and continuing to live in the old hut. Portions of the palm leaf covering the hut were torn, making a hole through which the twinkling stars glittered. The constellation Orion passed in the sky and the frogs and tadpoles croaked melodiously. It was deep into the night.

This time the old woman has been sick with malaria for several days. Her temperature has risen very high, making her deaf in both ears. She feels dizzy and is talking as if delirious in her sleep. The weather has changed, and it is hot and humid everywhere. The dark, sad clouds are hiding the moon. The wind blows stronger, becoming turbulent and shaking the whole country. The trees are like swings swaying in the rain. Flashes of lightning and thunder strike down with a deafening clap that shakes the whole world. The old woman is panic stricken and loses consciousness. Her body is soaked with rain. After a few hours, the storm tapers off. The sky begins to fill with the silver and golden rays of morning. The joyous chirping of the Boradok and Malaysian parrots can be heard clearly in the distance.

She has regained consciousness, but her fever has not abated. Poor dear, she is delirious. She is confused and goes down to pick some watercress. The watercress cries out in warning : "Grandma, don't come down here. There are dangerous snakes near the edge of the pond. They are mating." However, she does not hear the entreating voice and walks on down, straight ahead.

So it happens that, in a moment of fate, she steps on the tip of the tail of a vicious cobra. The cobra is startled. It swings around and bites her fully. The fangs are buried into her. She feels a sudden pain at the back of her foot, so she moves to soothe it with her hand. The cobra strikes again, this time at her hand, and she begins to realize that she has been bitten by a snake. Panic stricken, she loses consciousness, and fall at the edge of the pond. Before long, the deadly poison of the cobra works its way against the current of her bloodstream. In old age, the woman has little resistance. The poison forces itself through the blood into the depth of her heart, bringing her pulse to an end. The old woman breathes her last. But her eyes are still opened wide, as if to express her concern for the vegetables, trees, and flowers, who are her companions. Their friendship has no comparison. A portion of the waning moon still shows faintly and then disappears behind the trees. The day is beginning to dawn. The rain has abated some time ago. The air is calm and chilly, creating an atmosphere of solitude and silence, except for 
the reverberations of nature. Exploding dewdrops crackle on leaves. Only one lingering star still glitters in the immaculate womb of heaven.

For anyone having the power to hear beyond the range of the human ear the sobbing of the trees and flowers in that field would be very clear. The watercress, the papayas, the tamarinds, and the tamlyng shoots are all lamenting and weeping.

A tiny flower with a trembling voice said: "Older brothers and sisters, I am so unhappy because I was hoping this morning to bloom into a bright violet flower. If Grandma could have seen my brilliant colour it would have helped to relieve her pain. It is so sad." The tamlyng said: "Look at that. An army of fire ants is eating away at the pupils of Grandma's eyes. They are chewing away at her eyes in swarms. In a few days her corpse will rot and swell. The vultures and crows will peck at her body and feed from her flesh. Her bones will be scattered over the soil and sand. It is so pitiful."

After its lamentations, the tamlyng again begins to sob until tears come forth from the centre of its pure white blossoms. The tears blend with the dew and overflow the petals, as if they were a stream of remorse mourning the death of this old woman who has said farewell to the world and has disappeared forever.
A prose poem by Angkhan

Kalayanapong

English translation by Herbert

P. Phillips and Vinita ${ }^{11}$

In the text above we can see that Angkhan conveys to his readers various and complex aspects of nature. The 'conventional' and 'classical' aspect is still relevent - nature as man's benevolent supporter and a kind hearted friend, who is always willing to help and who will kindly satisfy all man's needs, like the concept expressed in Traibhumikatha.

However, in the text Grandma the poet chooses to express it in 'modern' terms when the vegetables and fruits offer themselves as 'healthy' food for grandma.

The papaya said to Grandma, 'I have a laxative that will clean your intestines and will make you feel more relaxed.'

The watercress in the pond said to Grandma, '... Grandma, proclaim to everyone that watercress is a superb medicine. After eating me, people's eyesight also improves.'

It is obvious that nature here is a source of 'goodness' for human beings in the 'physical' sense, which is a concept much advocated in our present time.

\footnotetext{
${ }^{11}$ Angkhan Kalayanapong, "GRANDMA," in Treasury of Thai Literature, ed. Prasert na Nagara, and others (Bangkok: The National Identity Board Office of the Prime Minister, 1988), pp. 195-199.
} 
Nevertheless, it is worth noticing that the poet also conveys a 'hostile' attitude of nature towards man in the 'criticism' of human nature (other than Grandma). The plants explain to Grandma that 'mankind's basic character and thought is composed of selfishness, small mindedness and avarice.'

Moreover, man is good at 'pretence, deception and intrigue', which plants would not be capable of. The plants also confess that they speak only to Grandma because they see that she is 'deserted and ignored uncompassionately by the rest of mankind'.

Here, we have a sense of 'conflict' rather than 'harmony' between nature and man, as nature no longer approves of man's behaviour towards nature and towards other human beings. Nature claims that the mal-treatment of nature by man and of man toward each other is the greatest 'barrier' or 'obstacle' for 'communication' between man and nature at the present time.

The result of the lack or the inability to communicate between nature and man is artistically conveyed in the text in the 'tragic' death of Grandma. Grandma cannot hear the warning of the watercress, she steps on a vicious cobra and is bitten twice by the poisonous snake.

The death of Grandma is described as her 'fate', which is very much a common belief in 'popular' Buddhism. Neverthe-less, it seems that nature is not aware of this 'fate' of Grandma. The trees, plants and flowers are all weeping for Grandma's death.

At the same time, we know that Grandma's death is not a 'peaceful' one because 'her eyes are still opened wide, as if to express concern for the vegetables, trees and flowers, who are her companions.'

Even though the reason for Grandma's concern is not directly conveyed by the poet, we can certainly understand that Grandma is worried for her friends, who will be badly treated by other human beings as they do not understand nor respect nature.

We know from the beginning that Grandma is quite prepared for her death as a good Buddhist. She tells the papaya that 'but for me, today is always the last day. Nothing is certain.'

Thus grandma is old and wise enough to accept death as a common process of life. Her fear for death is less than her worry for her companions such as the trees and the plants.

We can consider Grandma as a symbol of the wisdom of the past, that is now dying out, either slowly or rather abruptly, by uncontrollable and unexpected forces.

The description of Grandma's body being eaten by the fire ants and the vultures and crows is a great contrast to the overall description of nature in the text. Nature here is playing a different role of 'destroying'. The body is in the process of disintegration to become finally a part of the earth and the sand.

On the other hand, this process of 'destroying' can be viewed as a process of 'harmonizing' the body of Grandma with nature. Her body is, in fact, returning to be a part of nature.

Therefore, this 'pitiful' sight at the end of the story is another aspect of the 
harmony between man and nature that the poet is trying to convey.

From the analysis above, it is obvious that Angkhan successfully combines the classical concept of the harmony between man and nature to his own 'modern' concept. He explores various aspects of nature and convinces the reader of the 'ultimate' harmony between nature and man - that is, nature and man are one. They belong to each other.

Because they belong to each other, their relationship should be one of a strong harmony or even 'a bond of love and wisdom'. This message is clearly spelt out when the poet persuades us to follow the example of nature, whose generosity and kindness is equal to a Bodhisattva.

By the poet's referring to a Bodhisattva we can ultimately understand that the poet demands a spiritual wisdom and love of man for nature and perhaps vice versa. The bond of love and wisdom is beautifully expressed in the text of Grandma.

Through this text we can state quite clearly that the harmony between nature and man expressed in modern Thai poetry has transcended the literary convention of the past. Yet, at the same time, this harmony is still an essence of the exquisite beauty of Thai poetry, both in the literary and spiritual domain.

\section{References}

Angkhan Kalayanapong. GRANDMA. Prasert na Nagara, and others (eds.), Treasury of Thai Literature, pp. 195199. Bangkok: The National Identity Board Office of the Prime Minister, 1988.
Dhammadhibet, Prince. Verse for the Royal Barge Procession. Translated by Chamnongsri Rutnin, Khunying. Bangkok: T'NAT Printing Press, n.d.

Dhanit Yupho, Phraprawat Phraniphon Chao Fa Dhammadhibet. $5^{\text {th }}$ ed. Bangkok: Bannakarn, 1973.

James M. Gustafson... [et al.] Man and Nature : A Cross-Cultural Perspective. Bangkok: Chulalongkorn University Press, 1993.

Lithai, King. Traibhumikatha : The Story of the Three Planes of Existence. Translated by The Thai National Team. Bangkok: The ASEAN Committee on Culture and Information, 1985.

Manas Chitakasem, ed. Thai Literary Traditions. Bangkok: Chulalongkorn University Press, 1995.

Rama II, King. Inao. Bangkok: Silapabanakarn, 1971.

Suchitra Chongstitvatana. The Green World of Angkhan Kalayanapong : A Vision on Nature and Environment. Thai Literary Traditions, pp. 148-157. Bangkok: Chulalongkorn University press, 1995. 